\title{
An Empirical Evaluation Of Franchise Contracting Provisions In Spanish Chains
}

Rosa M Mariz Pérez, (Email: mtgarcia@udc.es), Universidad de A Coruña, Spain M Teresa García Álvarez, (Email: rosamp@udc.es), Universidad de A Coruña, Spain

\begin{abstract}
In this paper, we pretend to identify the existing differences between contractual conditions fixed by franchisors of Spanish chains. With this objective, we analyze the two basic types of existing franchised chains -those that commercialize services and those others that distribute productsand if contractual stipulations and other characteristics differ in a systematic manner between them. In this sense, we have considered a series of independent variables such as size, age, initial fee, royalties or contractual initial duration. After undergoing the descriptive analysis of these variables for our sample -440 Spanish franchised chains- we have divided the latter into two groups -based on the type of chain-in order to detect significant differences between them. For this aim, we have conducted a discriminant analysis to discover which of the independent variables taken into account contribute, in a significant manner, to a correct classification of chains to their corresponding group -service or product chains-.
\end{abstract}

\section{INTRODUCTION}



n concise terms, a franchise contract consists in a commercial collaboration system in which the franchisor -the owner of the chain- gives the franchisee the right to exploit a license or a recognized or successful brand name, to receive technical assistance and initial and on-going training, advertising support, etc. In exchange, the franchisee must undergo the necessary initial investments in his unit, pay the initial franchise fee and the periodical fees -royalty and advertising fees-, respect and apply the operating and commercial policies established by the franchisor, etc.

Franchising constitutes a hybrid organizational form, because it possesses both characteristics of hierarchy and the market. In this sense, as in hierarchy, the franchisor maintains a significant part of the control over the system through contractual provisions that the franchisee must comply with (opening and closing hours, regulation of the products and services that can and cannot be sold through each unit, presentation and decoration of the store, etc.). Nevertheless, it differs from hierarchy, and therefore, is closer to the market solution in that it allows for certain franchisee independence to decide over certain aspects that surely have a significant influence over his outlet.

The nature of residual rent distribution between parties is significantly different from that that would exist in the case of a totally decentralized system. In this sense, most franchise contracts include the payment of royalties for the franchisee, usually calculated as a percentage of unit sales, other on-going payments in exchange for certain services provided by the franchisor and the existence of an initial franchise entry fee. Moreover, the contract may obligate the franchisee to make purchases of certain critical inputs or raw materials from the franchisor or from authorised suppliers and usually contemplates the obligation for the owner of the chain to provide assistance and operating support to franchisees.

From another point of view, the existence of franchising has been justified through different, sometimes confronting, theories. First, it has been highlighted that the value of franchising is due to the capacity of franchisees of supplying scarce resources for the franchisor in the short term (Ozanne \& Hunt, 1971; Oxenfeldt \& Kelly, 19681969; Caves \& Murphy, 1976; Minkler, 1990, Norton, 1988). This would mean that reasons for franchising are only 
transitory because such shortages would disappear with time, so chains will franchise less with maturity and will, ultimately, be integrated only by franchisor-owned units.

Another view justifies the election of the franchisor to franchise based on agency considerations (Mathewson \& Winter, 1985; Brickley \& Dark, 1987; Norton, 1988; Lal, 1990). The franchisee gives solution to the incentive problem present in the case in which chain units are directed by employed managers and, therefore, this option reduces supervision and control costs. This will be especially relevant as geographical dispersion and importance of local agent effort increase (Lafontaine, 1992; Shane, 1996). As franchisor skills and knowledge increases, he will more effectively design incentive and compensation systems in order to control managers of his own stores and, therefore, franchising will be reduced.

Other authors have arrived at the opposite conclusion. They state that of is not he percentage of franchised establishments, but the percentage of franchisor-owned stores that decreases with chain maturity. In initial stages of chain life, the franchisor opens more directly-owned stores to signal his compromise to potential franchisees of protecting brand name value (Scott, 1995; Gallini \& Lutz, 1992; Lafontaine, 1993).

Nevertheless, recent studies consider that dual distribution or the so called "plural form" is a deliberate and stable strategy that entails important synergetic effects (Bradach, 1997; Lewin, 1997; Bai \& Tao, 2000; Sorenson \& Sorensen, 2001; Pénard et. al, 2002; Seshadri, 2002). Related to this, Lafontaine \& Shaw (2001) find that the proportion of franchisor-owned establishments is reduced in the first years of chain life-cycle and that, later on, it stabilizes around a certain percentage that varies from sector to sector and, moreover, from chain to chain.

There are common factors to all franchise contracts, but relevant differences also exist. For example, royalty fees, usually fixed as a percentage of unit sales, constitute one of the most important differing stipulations to the point that they are not even employed in some activities (Lal, 1990). If we take a look at the available annual franchise guidebooks, it is straightforward that there are relevant variations in their quantity. In this sense, the objective of the present paper is to determine if significant differences exist in contractual stipulations established by franchisors of Spanish chains, within these, royalty percentages are a key condition.

It is worth highlighting that contractual conditions are identical for all franchisees that join a given chain in a particular point of time. In spite of this, changing contractual terms, for a given chain, from one time period to another must be taken into account ${ }^{1}$.

Including a royalty rate in the franchise contract helps to align both parties' objectives, because both the franchisor and the franchisee will seek sales maximization (Lal, 1990; Bergen et. Al., 1992; Bhattacharyya \& Lafontaine, 1995). Because high royalties will supply franchisors with powerful incentives to control for and supervise activities to maintain and develop brand name value -therefore, we should expect royalties to be higher in the case of service chains compared to that of product distribution activities-, but will reduce franchisee motivation to be efficient, ownership of some units by the franchisor can constitute another manner of signalling his compromise with quality control. Even if horizontal free-riding hazards were eliminated, the existence of royalties would be necessary to motivate the franchisor to undergo the necessary investments in brand name ${ }^{2}$ (advertising,

\footnotetext{
${ }^{1}$ The evolution of economic contractual conditions is not analyzed in this paper, but will be treated in a future study once we have concluded data collection for the eight year period 1996-2003.

${ }^{2}$ Because royalty payments depend, usually, on gross sales, the franchisor signals his compromise to be diligent through making the necessary investment in brand name and detecting possible franchisee opportunistic behaviour. If a given franchisee decides to reduce product and/or service quality, his sales could be reduced. But, he would also have a subsequent reduction in his costs, with what he would still obtain "normal profits". Part of the consequences of his opportunistic behaviour would be spread among the rest of the franchisees and the franchisor of the chain (the latter has incentives to prevent this type of situation, because his earnings depend on franchisees units sales).

Instead, if royalty fees were related to franchisee profits, the franchisor would receive the same earnings even if the franchisee is a free-rider. So, in this case, he would not have the proper incentives to supervise franchisee behaviour. Related to this Rubin (1978) establishes that if royalties are tied to profits, the franchisor would not be signalling his compromise of being diligent. Whereas, if they depend on gross sales, he would be affected through reduced payments received for this concept and would be motivated towards detecting reduced quality (Rubin, 1978; Lal, 1990).
} 
franchisee selection and control, etc.). Due to the fact that neither the level of service supplied by the franchisee or franchisor' specific investments can be totally contemplated in a contract, and because they are not easily observed, parties have incentives to act in an opportunistic manner.

The franchisor has an important paper in reducing franchisee opportunism or free riding -because the latter may try to reduce quality standards to decrease his corresponding costs (in a greater quantity than reductions suffered in sales) and this will have a negative effect over all units of the chain- and in providing other services, like advertising, that can be undergone more efficiently if they are centralized. It is observed that in order to extract rents form franchisees they rely more on royalties than on high initial fees (Rubin, 1978; Seaton, 2003).

In another order of things, the presence of an adequate proportion of franchisor-owned establishments can also contribute to the reduction of differences in quality supplied through multiple units. Uniformity is, in this sense, one of the key characteristics of chain success and units owned by the franchisor can help to enhance it through reduction of franchisee opportunism. Therefore, we will probably a negative relation between royalty intensity quantity- and the proportion of franchisor-owned units because both work towards reducing incomplete and asymmetrical informational hazards (Pénard et. Al, 2003).

Related to the above, various studies have found that there is a negative relation between the importance of franchisee effort and the proportion of units owned by the franchisor (Norton, 1988; Lafontaine, 1992; Shepard, 1993; Slade, 1996; Lafontaine \& Slade, 1997). This is to say that when control and supervision of effort becomes specially difficult or costly, as in activities labour intensive activities, the franchisor relies on high-powered incentives and prefers to share the residual rent with the agent (Brickley \& Dark, 1987; Minkler, 1990; Scott, 1995). Therefore, because service chains need for increased effort from the local agent, we expect to find that franchising is widespread and this will reduce the proportion of franchisor-owned units compared to product distribution chains.

Based on the above, the objective of this paper is twofold. First, the descriptive analysis of contractual conditions fixed by Spanish franchised chains. With this aim, we have employed data supplied by annual guidebooks for the year 2002. Second, from a static point of view, we conduct a discriminant analysis to shear some light on how contractual stipulations vary with chain activity in Spain. More specifically, if significant differences exist between terms established by franchisors whose activity consists in commercializing services and those that distribute products they manufacture themselves.

The rest of the paper is structured as follows. First, we identify and describe the variables taken into account and we try to anticipate the sign or expected relation with each type of chain. Secondly, we refer to data collection and methodology employed and, in the next section, we present the results obtained. Lastly, we make reference to the mayor conclusions.

\section{KEY VARIABLES}

\section{Royalty rate (ROY)}

This variable represents the periodic payments - usually depending on gross sales- that franchisees must make to franchisor. It is measured as the percentage established in the franchise contract. We include in this rate the percentage of advertising fees that the franchisee must also supply to the chain owner because, in many cases, one rate in included in the other.

As in other studies, a small proportion of the chains in the sample did not establish royalty fees as a percentage of sales. Royalty payments in these cases were established as a fixed periodical sum. Theses

Nevertheless, Tikoo \& Nair (1999) highlight that even though the above is true; it gives rise to another problem. So, they propose variable royalty rates because while franchisors are interested in maximizing all units' sales, franchisees really seek maximizing their surplus. Therefore, franchisees will only be motivated towards increasing their sales when marginal sales exceed marginal costs (when both become equal, the optimum point is reached and if marginal profit becomes negative, franchisor and franchisee objectives are in conflict) (Spinelli \& Birley, 1996; Fladmoe-Lindquist \& Jacque, 1995). 
observations, as in Brickley (2002) were eliminated from the sample -finally, we obtained 440 valid Spanish chains. Royalty fees are obligated for all franchisees of the chain and, therefore, constitute an important portion of franchisor remuneration. These payments compensate the latter for the investments made in developing brand name value, supporting and training franchisees, supervising them, etc. it is for this reason that we expect to find that royalty rates are greater in chains that are dedicated, more intensively, to the commercialization of services. In this case, it seems straightforward that initial transmission of franchisor intangible assets to franchisee and monitoring needs are greater.

\section{Age; number of years franchising (YF) and number of initial years without franchising (YNOTF)}

The number of years franchising is defined as the period of time, measured in years, between the year the chain was established -the year the first franchised unit was opened- and the present year -in this case, 2002-. This time period is commonly used as a proxy for chain experience. In this sense, greater experience may permit easier access to scarce resources for the franchisor or can reflect chain reputation value. We expect to find that the number of years franchising is greater in service chains, given that that this type of activities demand more franchisor experience and skills to transfer know how and other intangibles to franchisee and, also, to monitor them efficiently.

The number of years without franchising -period of time, in years, between the year the enterprise was established and the year the first franchised unit was opened- is employed as a proxy to measure franchisor difficulties in developing an adequate franchising package. Moreover, chains with a higher value for this variable should present a smaller number of franchised units because during the initial period without franchising, centralized organizational and control systems are installed; this is, at least in Spain, a feature difficult to change.

We expect that the value of years without franchising to be higher in service chains because it can reflect brand name value (Lafontaine, 1992; Lafontaine \& Shaw, 2001; Pénard et. Al. 2002), franchisor skills to select franchisees or time needed to develop and complete franchise package.

\section{Size of the chain (SIZE)}

Chain size is measured as the total number of units of the chain -franchised and franchisor-owned-. The value of this variable should be superior in product distribution chains because in service chains expansion can be slowed due to higher monitoring and uniformity problems. As a consequence, previous studies have stated that chain size presents a very high positive correlation with geographical dispersion and, therefore, can be used as a proxy for supervision costs (Brickley \& Dark, 1987; Lafontaine \& Slade, 2001).

\section{Initial complementary investment -total investment minus initial entry fee- (INV)}

This variable represents the initial complementary investment the franchisee must make in order to join the chain -total initial investment minus initial entry fee.

Basically, it is the sum of costs of adapting store premises to franchisor stipulations. We expect the value to be higher for service chains because in this type of activities a relevant portion of "production" must be made locally -for example, in the case of restaurants-.

\section{Initial entry fee (CAN)}

The initial entry fee the franchisee must support to join the chain is justified through the existence of a successful and proven bran name, the right to receive operating assistance from the franchisor, the transfer of know how from the franchisor, etc.

It has been established that this fee and royalties constitute alternative manners of extracting rents or surplus from franchisees in order to prevent the latter to obtain extraordinary profits (Blair \& Kaserman, 1982; Kaufmann \& Dant, 2001). So, we should find a negative relation between both variables. 
Nevertheless, other studies have found a positive relation between CAN and ROY. For example, Mathewson \& Winter (1985) established that lower entry fees correspond to chains that also fix lower royalty rates and that this was a common practice among chains that are merged in initial phases of their life cycle, -this is, chains with lower brand name value-. Related to this, Lafontaine \& Kaufmann (1994) found that both variables offered the same evolution patterns over time. They justified their finding stating that these fees correspond to different remuneration concepts. This way, while the entry fee is applied by the franchisor to recover initial selection and training costs, royalty fees are used to pay for brand name value and on-going support given to franchisees, so we may find a positive correlation between both (Lafontaine, 1992; Lafontaine \& Shaw, 1999).

We should expect CAN to be higher the higher the importance of intangible assets transfer to franchisees and this takes place in service chains.

\section{Contract duration (DUR)}

This variable reflects the initial duration, provided in the contract, for the relation between franchisor and franchisee. Shorter contract duration will reduce the number of potential franchisees willing to join the chain and, therefore, increase the proportion of franchisor-owned units. Moreover, longer durations will probably lead to lower royalty rates because as the franchisor has more experience, he usually will prefer to extract rents from franchisees through longer contract periods instead of employing higher royalty rates (Pénard et. Al. 2002).

We expect duration to be longer in service chains in order to permit franchisees to more easily recover initial investments made.

\section{Proportion of franchisor-owned units (\%PROP)}

We obtain the values of this variable by dividing the number of franchisor-owned units into the total number of establishments of the chain. Although it is not a contractual stipulation, we consider it is a key variable in the design of any franchise chain.

The proportion of units owned by the franchisor will be, quite surely, higher in product distribution chains because the importance of local agent effort is lower in this type of activities. Moreover, as in Pénard et. al. (2002), we will also consider the relation between this variable and royalty rates. Both of them work towards the reduction of contractual hazards that arise due to incomplete and asymmetrical information situations. This may mean that both constitute alternative mechanisms in organizational design of franchise chains -negative relation-. Commonly, most papers that have studied franchise contractual conditions (Lafontaine, 1992; Lafontaine \& Shaw, 1999; Bercovitz, 2000, Scott, 1995) have not gone deeply into the relation between royalties and the so-called "dual or plural distribution".

After the descriptive analysis of the previous variables for the total sample, we divided it into two groups based on chain type. For this purpose, we introduced a dummy variable -TYPE- that is equal to zero when chain activity consists in commercializing services and equal to one if it entails the distribution of products manufactured centrally by the franchisor. The ultimate aim of this classification is to analyze the possible existence of significant differences in contractual stipulations and in the proportion of franchisor-owned units between both groups.

\section{DATA}

Due to the non existence of a ready to use dada base related to franchising in Spain, data employed has been collected, in collaboration with a working group of the University of Oviedo (Spain) ${ }^{3}$, from the annual franchise guidebooks published. We have drawn data from Tormo \& Asociados, Barbadillo \& Asociados, Franchisa and Asociación Española de Franquiciadores.

\footnotetext{
${ }^{3}$ We specially thank Prof. Manuel González and Prof. Begoña López for their help.
} 
The final specific sample used is integrated by Spanish chains that had, at least, one establishment in 2002. This was the analyzed and guidebooks contained references for more than 1500 Spanish chains. In many cases, sufficient data was not available, so they were not taken into account. Finally, the sample is composed by 440 chains.

Related to data collection, we must make reference to important incongruent information between guidebooks. In this sense, in some cases, for the same year and variable, guidebooks contained very different values. To give solution to this problem we contacted with the franchisor, on the telephone or web page with the aim of reflecting the true value of the variable. Nevertheless, when this was not possible we took the value proportioned by Tormo \& Asociados because this guidebook had resulted, in other occasions, that it was the most accurate.

In some cases, data for some variables was available in interval terms. In these cases, franchisors reported a maximum and minimum because exact numerical value depended on other circumstances like unit location or dimension, so we introduced the average of the variable.

Chains finally selected belong to all the different sectors of activity that are present in franchising activities. It is worth mentioning that each annual guidebook includes around 60 different activities. Given the size of the sample, we chose to regroup these activities into 14 larger sectors $\mathrm{n}$ such a way that each one corresponds, unequivocally, to service or product distribution chains. Controlling for sector differences is to be done in a future, more complete, contribution. In this sense sectors belonging to "product chains" (TYPE $=1)$ are: cosmetics and dietetic products, furniture and house clothing, computers and accessories, clothing, shoes and accessories, specialized products and various products. In the same line "service chains" (TYPE $=0$ ) include bars and restaurants, fast food, photograph and optic, real-estate agency and consulting services, personal health and fitness, specialized services and telephone and communications. This classification was taken into account both in the descriptive and discriminant analysis.

\section{RESULTS}

First, Table 1 summarizes the basic descriptive analysis of all variables used (minimum, maximum, mean and standard deviation). It can be observed that franchising in Spain is a fairly new activity because chains have been franchising an average of 6.18 years. There are two notable exceptions to this: YF is 82 -maximum value- and 71 for two distribution chains. Another fifty chains have started to franchise in 2002, so a zero value is reflected for this variable in these cases.

As for YNOTF, at average chains in the sample have initially stayed 8.67 years without franchising, one hundred and two started franchising from the very moment of firm establishment and one chain -a chocolate producer- waited 170 years to start to open franchised units.

\begin{tabular}{|c|c|c|c|c|}
\hline & Min. & Max. & Mean & Stand. Desv. \\
\hline YF & 0 & 82 & 6,18 & 7,16 \\
\hline YNOTF & 0 & 170 & 8,67 & 17,21 \\
\hline SIZE & 1 & 2449 & 54,31 & 156,89 \\
\hline \% PROP &, 000 & 1,00 &, 328 &, 288 \\
\hline INV &, 00 & 1896193,19 & 89610,82 & 133726,77 \\
\hline CAN &, 00 & 300506,05 & 12951,51 & 18718,18 \\
\hline DUR & 1 & 15 & 6,79 & 2,63 \\
\hline ROY &, 00 &, 60 &, 04 &, 05 \\
\hline
\end{tabular}

Table 1: Basic descriptive analysis of variables for the total sample $(\mathrm{N}=440)$ 
Spanish chains are relatively small or medium sized given that they have a mean value for SIZE of 54 units. Ten chains only have one unit and DIA-PREKO -a widely spread supermarket- has 2449.

As for the percentage of franchisor-owned units (\%PROP), the average value is near 33\%. Nevertheless, for those chains that only have one or few units that are franchisor-owned -eighteen- \%PROP reaches its maximum value. There are also fourteen chains integrated exclusively by franchised establishments.

With reference to the economic stipulations of franchise contracts, initial entry fee (CAN) is at average of 12951 euros. It is worth noting that in Spain for 117 chains this payment did not exist -this supposes $26 \%$ of the sample-. Again, the highest value for this variable was for DIA-PREKO -around 300500 euros-.

The mean value for the complementary or additional investment required to join the chain (INV) is 89610 euros. In the sample, thirteen chains did not entail any additional investment while for By Print $-\mathrm{a}$ franchise chain in the digital print activity- requires franchisees to undergo the highest investments in equipment and store -nearly 1900000 euros-.

Contract duration (DUR) never is superior to 15 years. The average value is 6.8 years but some chains only fix an initial duration of 1 year. We must take into account that most chains offer periodical renovations once initial duration is completed.

The existence of royalties is not contemplated in 117 chains. The maximum value is $60 \%$ even though the mean value is $4 \%$.

Table 2 presents descriptive analysis of variable once we have separated total sample in two groups- service and product chains. Basically, we can observe that dispersion has been reduced for most variables. Moreover, mean values for YF, YNOTF, SIZE and \%PROP are higher for product distribution chains compared to service chains. The opposite occurs for INV, CAN, DUR and ROY. Nevertheless these differences, as we will see below, are not always significant from a statistical perspective.

Next, we perform a means difference test, based on Wilks' Lambda value, to discover which variables are best at differentiating service from product chains. In this sense, the values of some variables are statistically different for one type of chains compared to the other.

This way, test shown in Table 3 establishes that DUR, ROY, PROP and YF are significant at $1 \%$. Therefore, we can say that service chains establish a higher rate for periodical payments to franchisors compared to that of product distribution chains. This is consistent with the idea that the first type of activities entail more important transfers of intangibles assets from franchisor to franchisees and that this also leads to greater needs of ongoing support and training. This mayor intensity of these franchisor activities is compensated through increased periodical payments.

Initial duration fixed in the contract for party relation is also systematically higher in service chains. It seems franchisees need longer time periods to recover high initial investment -complementary investment and entry fee- associated with service chains. Another possible explication to why service chains establish longer duration periods is that this reduces adverse selection hazards for the franchisor. Although CAN is not found to be statistically different in this analysis, the additional initial investment -INV- is, at average, higher in service chains, as was expected. 


\begin{tabular}{|l|c|c|c|c|c|}
\hline & Variable & Min. & Max. & Mean & Stand. Desv. \\
\cline { 2 - 6 } & YF & 0 & 33 & 5,09 & 5,088 \\
\cline { 2 - 6 } & YNOTF & 0 & 92 & 7,63 & 14,02 \\
\cline { 2 - 6 } TYPE: 0 & SIZE & 1 & 1040 & 50,33 & 124,47 \\
\cline { 2 - 6 } SERVICE & \% PROP &, 000 & 1,000 &, 289 &, 262 \\
\cline { 2 - 6 }$(\mathbf{N = 2 4 9 )}$ & INV &, 0 & 1896193,20 & 104664,33 & 162909,22 \\
\cline { 2 - 6 } & CAN &, 00 & 180303,63 & 14866,22 & 14710,93 \\
\cline { 2 - 6 } & DUR & 1 & 15 & 7,37 & 2,77 \\
\cline { 2 - 6 } & ROY &, 00 &, 60 &, 050 &, 056 \\
\hline \multirow{4}{*}{$\begin{array}{l}\text { TYPE: } 1 \\
\text { PRODUCT } \\
\text { CHAINS } \\
\text { (N=191) }\end{array}$} & YF & 0 & 82 & 7,59 & 8,99 \\
\cline { 2 - 6 } & YNOTF & 0 & 170 & 10,02 & 20,60 \\
\cline { 2 - 6 } & SIZE & 1 & 2449 & 59,46 & 191,11 \\
\cline { 2 - 6 } & INOP &, 000 & 1,000 &, 377 &, 313 \\
\cline { 2 - 6 } & CAN &, 00 & 633370,6 & 69986,09 & 77419,26 \\
\cline { 2 - 6 } & DUR & 1 & 100506,05 & 6,02 & 22532,74 \\
\cline { 2 - 6 } & ROY &, 00 &, 38 &, 026 &, 04 \\
\hline
\end{tabular}

Table 2: Basic descriptive analysis of variables for service chains $(\mathrm{N}=249)$ and product distribution chains $(\mathrm{N}=191)$

Another significant variable is shown to be \%PROP. Service chains choose to grow through more franchised units. Therefore, the proportion of franchisor-owned establishments is smaller in this type of activities. This is probably due to increased incentive and effort hazards present in the commercialization of services, where the importance of local agent effort is a key factor of success. On the other hand, product distribution chains can rely more intensely on units owned by the franchisor to grow, because uniformity and quality -two aspects positively related to agent effort- is less important at a local level given that production is done centrally.

\begin{tabular}{|c|c|c|c|}
\hline & Wilks Lambda & F & Sig. \\
\hline YF &, 975 & 5,942 &, 010 \\
\hline YNOTF & 1,000 &, 028 &, 868 \\
\hline SIZE &, 997 &, 746 &, 389 \\
\hline INV &, 980 & 4,607 &, 033 \\
\hline \% PROP &, 970 & 7,063 &, 008 \\
\hline CAN &, 996 &, 880 &, 349 \\
\hline DUR &, 932 & 16,684 &, 000 \\
\hline ROY &, 888 & 29,008 &, 000 \\
\hline
\end{tabular}

Table 3: Means Differences between both groups

A negative relation seems to exist between the proportion of franchisor-owned units and established royalty rates and this is consistent with the idea that both constitute alternative mechanisms to monitor franchisees.

YF also results significant and is higher for product distribution chains, contrary to what we expected. The remaining variables do not present significant different value for the two types of activities.

Below, we present results for discriminant analysis through a stepwise estimation -this process estimates the discriminant function by entering the independent variables sequentially according to the discriminatory power they add-. 


\begin{tabular}{|c|c|c|c|c|}
\hline \multirow{2}{*}{ Step } & \multirow{2}{*}{ Introduced } & \multirow{2}{*}{ Tolerance } & & \\
\hline & & & $\mathbf{F}$ & Sig. \\
\hline 1 & ROY & ,888 & 29,008 &, 000 \\
\hline 2 & \% PROP & 850 & 20,193 &, 000 \\
\hline 3 & DUR & 809 & 18,001 &, 000 \\
\hline 4 & YF & ,790 & 15,123 &, 000 \\
\hline
\end{tabular}

Table 4: Variables introduced in each step of discriminant analysis

As displayed in Table 4, the first variable to be entered is ROY because it contributes, in a greater extent, to explain dependent variable. In next steps, \%PROP, DUR and YF are included. These four independent variables are significant in discriminating between groups.

Tolerance, that represents the variation in the corresponding independent variables not explained by the variables already included in the model, are relatively high. This can be used to estimate multicollinearity problems, which in this case, are reduced. The rest of the results are presented through Table 5 to Table 8 . As observed, the model classifies adequately the $68.4 \%$ of total cases of the sample.

\begin{tabular}{|c|c|c|c|c|c|c|}
\hline Function & Eigenvalue & $\begin{array}{c}\text { \% of } \\
\text { variance }\end{array}$ & $\begin{array}{c}\text { Canonical } \\
\text { correlation }\end{array}$ & $\begin{array}{c}\text { Wilks' } \\
\text { Lamba }\end{array}$ & Chi-square & Sig. \\
\hline 1 &, 266 & 100,0 &, 459 &, 790 & 53,864 &, 000 \\
\hline
\end{tabular}

Table 5: Discriminant analysis results

\begin{tabular}{|l|c|}
\hline & Function \\
\cline { 2 - 2 } & $\mathbf{1}$ \\
\hline YF &,- 348 \\
\hline \% PROP &,- 634 \\
\hline DUR &, 519 \\
\hline ROY &, 590 \\
\hline
\end{tabular}

Table 6: Standardized coefficients for canonical discriminant function

\begin{tabular}{|l|c|}
\hline & Function \\
\cline { 2 - 2 } & $\mathbf{1}$ \\
\hline ROY &, 688 \\
\hline DUR &, 522 \\
\hline \% PROP &,- 339 \\
\hline YF &,- 311 \\
\hline SIZE(a) &,- 190 \\
\hline INV(a) &, 085 \\
\hline CAN(a) &, 050 \\
\hline YNOTF(a) &, 002 \\
\hline
\end{tabular}

Table 7: Correlations between discriminating variables and typified canonical discriminant functions

(a) This variable in not used in the analysis. 


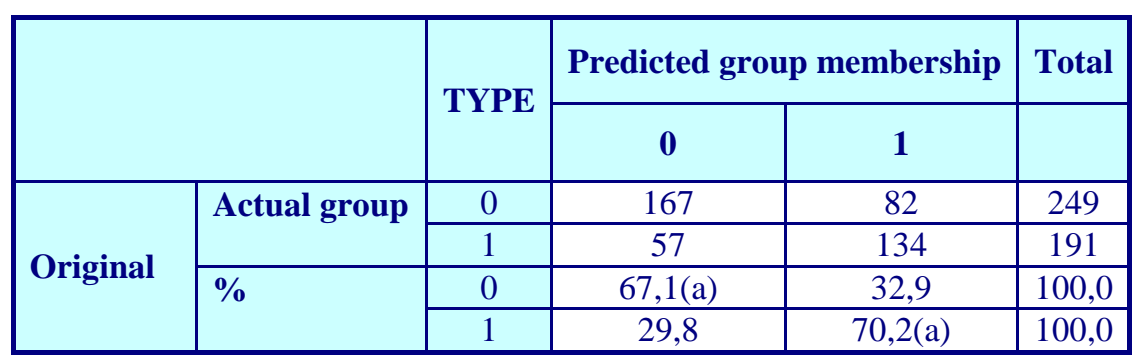

Table 8: Final classification matrix

(a) The function classifies $68.4 \%$ of chains correctly

From the information given above, we can say that service chains entail larger royalty payments from franchisees, fix longer initial duration periods, present a lower proportion of franchisor-owned units and, at average, have been franchising for less time compared to product distribution chains. This last finding is contrary to what was initially expected because it is supposed that the more important the transfer of intangible assets to franchisees and the more monitoring difficulties, the larger the value of YF.

Form another point of view, we must make reference to the fact of variables, which in other studies were clearly significant, did not prove to be so here -SIZE, CAN, YNOTF and INV-. Related to SIZE, is seems that increased complexity in design, supervision and control of the system does not influence growth possibilities because both types of chains reach a comparable number of units.

More surprisingly, the initial franchise entry fee -CAN- is not significantly different between groups, so we cannot say that service chains charge larger CAN compared of that established by product chains. The same can be said for the complementary initial investments -even though, this variable was significant at a level of 0.05 in the means difference test-.

Years without franchising -YNOTF- does not supply relevant discriminating power either. This is contrary to our expectations and indicates that the franchisor does not find greater difficulties to develop the franchise package in the case of service activities.

\section{CONCLUDING REMARKS AND FUTURE EXTENSIONS}

In this paper, we have intended to identify the existing differences in contractual stipulations and other chain characteristics between the two basic types of chains.

Contractual theories and resource based theory highlight relevant differences in these conditions as a function of the nature of chain basic activity, this is, between service and product distribution chains. To apply this to Spanish chains, we have conducted a means difference test and a stepwise discriminant analysis. The latter correctly classified over a $68 \%$ of the total sample -440 chains-.

Findings include that royalty percentages -ROY-constitute the most discriminating variable between groups and are significantly higher in service chains.

In the next step, the variable entered in the discriminant function was \%PROP, with what we can say that service chains use more franchised units and less franchisor-owned units compared to product chains. The importance of agent effort and monitoring hazards associated with activities that employ, more intensively, labour leads the franchisor to rely on surplus sharing with local agent.

The variable entered in step 3 is contractual duration. DUR is longer in service chains and this permits, on one hand, easier investment recovery for franchisee, and on the other, reduced adverse selection hazards for the 
franchisor. Once the franchisee has joined the chain, to extract rents to recover higher intangible investments through longer relations.

Another relevant finding is that royalty rates and the proportion of franchisor-owned units seem to present a certain substitute relation. In this sense, when one is higher the other is lower and this indicates that they may be alternative incentive and monitoring mechanisms.

The last variable that significantly discriminates between both types of chains is the number of years franchising -YF-. Service chains appear to start franchising activities later compared to product distribution chains, but once they start they employ it more intensively.

Lastly, we must make reference to our future intention of extending the present study to include the evolution pattern of these variables over a given period of time. In this sense, with panel data, we could analyze interaction between key variables for each chain in the period taken into account. With this aim, we have just concluded the data collection phase for the eight year period from 1996 to 2003 and we are completing this information with other financial values not included in annual guidebooks. The necessity of controlling for differences within each type of activity -service and product chains- will also be taken into account.

\section{BIBLIOGRAPHIC REFERENCES}

1. Bai, C. E. \& Tao, Z. (2000): “Contract Mix in Franchising”, Journal of Economics and Management Strategy, vol. 9, no 1, pp. 85-113.

2. Bercovitz, J. E. (2000): “An Analysis of the Contract Provision in Business Format Agreements", Working Paper, Fuqua School of Business, Duke University.

3. Bergen, M.; Dutta, S. \& Walker, O. C. (1992): "Agency Relationships in Marketing: A Review of the Implications and Applications of Agency and Related Theories", Journal of Marketing, vol. 56, no 3, pp. 124.

4. Bhattacharyya, S. \& Lafontaine, F. (1995): "Double-sided Moral Hazard and the Nature of Share Contracts", Rand Journal of Economics, vol. 26, no 2, pp. 761-781.

5. Blair, R. D. \& Kaserman, D. L. (1982): “Optimal Franchising”, Southern Economic Journal, vol. 49, no 2, pp. 494-505.

6. Bradach, J.L. (1997): "Using the Plural Form in the Management of Restaurant Chains", Administrative Science Quarterly, vol. 42, pp. 276-303.

7. Brickley, J. A. (2002): Royalty Rates and Upfront Fees in Share Contracts: Evidence from Franchising", Journal of Law, Economics \& Organization, vol. 18, no 2, pp. 511-535.

8. Brickley, J.A. \& Dark, F.H. (1987): "The Choice of Organizational Form: The Case of Franchising", Journal of Financial Economics, vol. 18, pp. 401-420.

9. Caves, R. E. \& Murphy, W. F. (1976): "Franchising: Firms, Markets and Intangible Assets", Southern Economical Journal, vol. 42, pp. 572-586.

10. Fladmoe-Lindquist, K. \& Jacque, L. (1995): "Control modes in international service operations: the propensity to franchise", Management Science, vol. 41, no 7, pp. 1238-1249.

11. Gallini, N. T. \& Lutz, N. (1992): "Dual Distribution and Royalty Fees in Franchising", Journal of Law, Economics \& Organization, vol. 8, pp. 471-501.

12. Kaufmann, P. J. \& Dant, R. P. (2001): “The Pricing of Franchise Rights”, Journal of Retailing, vol. 77, pp. 537-545.

13. Lafontaine, F. (1992): “Agency Theory and Franchising: Some Empirical Results”, Rand Journal of Economics, vol. 23, pp. 263-283.

14. Lafontaine, F. (1993): "Contractual Arrangement as Signalling devices: Evidence from Franchising", Journal of Law, Economics \& Organization, vol. 9, pp. 256-289.

15. Lafontaine, F. \& Kaufmann, P. (1994): "The evolution of ownership patterns in franchise systems", Journal of Retailing, vol. 70, no 2, summer, pp. 97-113.

16. Lafontaine, F. \& Shaw, K. L. (1999): The Dynamics of Franchise: Evidence from Panel Data", Journal of Political Economy, vol. 107, pp. 1041-1080. 
17. Lafontaine, F. \& Shaw, K. L. (2001): "Targeting Managerial Control: Evidence from Franchising", Working Paper, University of Michigan Business School.

18. Lafontaine, F. \& Slade, M. (1997): "Retail Contracting: Theory and Practice", The Journal of Industrial Economics, vol. 45, no 1, pp. 1-25.

19. Lafontaine, F. \& Slade, M. (2001): "Incentive Contracting and the Franchise Decision", en Chatterjee, K. \& Samuelson, W. (eds.): Advances in Business Application of Game Theory. Kluwer Academic Press.

20. Lal, R. (1990): "Improving channel coordination through franchising", Marketing Science, vol. 9, no 4, fall, pp. 299-318.

21. Lewin, S. (1997): "Innovation and authority in franchise systems: toward a grounded theory of the plural form", Doctorate Thesis, Department of Economy, Harvard University, Cambridge.

22. Mathewson, G.F. \& Winter, R.A. (1985): "The economics of franchise contracts", Journal of Law and Economics, vol. 28, no 3, pp. 503-526.

23. Minkler, A. (1990): “An Empirical Analysis of a Firm Decision to Franchise”, Economic Letters, vol. 34, pp. 77-82.

24. Norton, S.W. (1988): "Franchising, brand name capital and the entrepreneurial capacity problem", Strategic Management Journal, vol. 9, pp. 105-114.

25. Oxenfeldt, A. \& Kelly, A. (1968-1969): "Hill Successful franchise Systems Ultimately Become WhollyOwned Chains?", Journal of Retailing, vol. 44, no 4, winter, pp. 69-83.

26. Ozanne, U. B. \& Hunt, S. D. (1971): "The Economic Effects of Franchising”, Select Comm. On Small Business, US Senate, 92 Congress.

27. Pénard, T.; Raynaud, E. \& Saussier, S. (2002): "Dual distribution and royalty rates in franchised chains. An empirical analysis using French data", Journées de Microéconomie Appliquées Rennes-Saint Malo.

28. Rubin, P.H. (1978): "The theory of the firm and the structure of franchise contract", Journal of Law and Economics, vol. 21, pp. 223-233.

29. Scott, F. A. (1995): "Franchising vs. Company Ownership as a Decision Variable of the Firm", Review of Industrial Organization, vol. 10, pp. 69-81.

30. Seaton, J. (2003): “An analysis of UK franchise contracting 1989-1999", Managerial and Decision Economics, vol. 24, no 1, pp. 25-34.

31. Seshadri, S. (2002): "Outlet Ownership in Franchising Systems: An Agency Based Approach”, Managerial and Decision Economics, vol. 23, pp. 355-369.

32. Shane, S. (1996): "Hybrid organizational arrangements and their implications for firm growth and survival: A study of new franchisors", Academy of Management Journal, vol. 31, no 1, pp. 216-234.

33. Shepard, A. (1993): "Contractual Form, Retail Price and Asset Characteristics", Rand Journal of Economics, vol. 24, pp. 58-77.

34. Slade, M. E. (1996): "Multitask Agency and Contract Choice: An Empirical Assessment", International Economic Review, vol. 37, pp. 465-486.

35. Sorenson, O. \& Sorensen, J. (2001): "Finding the right mix: franchising, organizational learning and chain performance"; Strategic Management Journal, vol. 22, pp. 713-724.

36. Spinelli, S. \& Birley, S. (1996): "Toward a theory of conflict in the franchise system", Journal of Business Venturing, vol. 11, pp. 329-342.

37. Tikoo, S. \& Nair, S. (1999): "Variable royalty rates for improving franchise channel coordination", Decision Science, vol. 30, no 2, pp. 469-479. 